\title{
Nutritional value of three Blattodea species used as feed for animals
}

\author{
M. Kulma ${ }^{1,4}$, V. Plachý2 ${ }^{2}$ L. Kouřimskáa ${ }^{2}$ V. Vrabec ${ }^{1}$, T. Bubová1, A. Adámková ${ }^{3}$ and B. Hučko ${ }^{2}$ \\ Czech University of Life Sciences Prague \\ ${ }^{1}$ Department of Zoology and Fisheries, ${ }^{2}$ Department of Microbiology, Nutrition and Dietetics \\ ${ }^{3}$ Department of Quality of Agricultural Products \\ Kamýcká 129, 16500 Praha-Suchdol, Czech Republic
}

KEY WORDS: Blattodea, nutritional value, amino acids, fatty acids

$\begin{array}{lr}\text { Received: } & 2 \text { January } 2016 \\ \text { Revised: } & 9 \text { August } 2016 \\ \text { Accepted: } & \text { 12 December } 2016\end{array}$

${ }^{4}$ Corresponding author: e-mail: kulma@af.czu.cz

\begin{abstract}
Nutrient contents of subadult and adult Blaptica dubia, Blaberus discoidalis and Blatta lateralis roaches, commonly used as feed source for insectivorous animals in captivity, were determined. Contents of crude protein, fat, ash, chitin, carbohydrates, calcium and phosphorus were analysed. Adults of all species contained more crude protein $\left(602-678 \mathrm{~g} \cdot \mathrm{kg}^{-1} \mathrm{DM}>\right.$ $\left.489-547 \mathrm{~g} \cdot \mathrm{kg}^{-1} \mathrm{DM}\right)$ and ash (42-51 $\left.\mathrm{g} \cdot \mathrm{kg}^{-1} \mathrm{DM}>36-40 \mathrm{~g} \cdot \mathrm{kg}^{-1} \mathrm{DM}\right)$ but less fat (145-214 g $\left.\cdot \mathrm{kg}^{-1} \mathrm{DM}<236-363 \mathrm{~g} \cdot \mathrm{kg}^{-1} \mathrm{DM}\right)$ than subadults. Chitin content ranged $53-86 \mathrm{~g} \cdot \mathrm{kg}^{-1} \mathrm{DM}$ and the calcium to phosphorus ratio was 1:1.9-23.5. Amino and fatty acid profiles were also determined. Very high levels of glycine $\left(66.4-166.2 \mathrm{~g} \cdot \mathrm{kg}^{-1} \mathrm{DM}\right)$ and alanine $\left(81.5-118.4 \mathrm{~g} \cdot \mathrm{kg}^{-1} \mathrm{DM}\right)$ were found in all examined samples. On the other hand, the lowest amino acid levels were determined in such sulphuric amino acids as cysteine $\left(0.5-2.1 \mathrm{~g} \cdot \mathrm{kg}^{-1} \mathrm{DM}\right)$ and methionine (4.0-17.2 $\left.\mathrm{g} \cdot \mathrm{kg}^{-1} \mathrm{DM}\right)$. Regarding essential amino acids, very high lysine (48.6-94.0 $\left.\mathrm{g} \cdot \mathrm{kg}^{-1} \mathrm{DM}\right)$ and valine (53.3-84.0 $\left.\mathrm{g} \cdot \mathrm{kg}^{-1} \mathrm{DM}\right)$ levels were determined. Essential amino acid index was found at the level of $0.4-0.9$. In analysed cockroaches high oleic (38.0-44.2\%), linoleic (8.5-15.3\%) and palmitic (21.6-26.8\%) fatty acids levels were determined. The obtained results indicate that quantity of protein and lipids varied between subadult and adult cockroaches within the species, while quality of these nutrients remained stable.
\end{abstract}

\section{Introduction}

Unlike the past when insects were primarily used as feed for companion animals, today the usage of insects as an alternative source of nutrients in farm animal diets is also considered. The insects are generally known to be a sufficient source of protein and lipids. However, the nutritional requirements of animals are specified not only by nutrients quantity but also quality. Although the amino acid profile is the decisive characteristic of protein quality, it's composition is known only for a few insect species. Yi et al. (2013) reported insect protein quality to be higher than soyabean and lower than casein proteins. Barroso et al. (2014) stated that amino acid profile of some Diptera is superior to soyabean meal.

From this point of view, the insect protein quality could also be compared with some conventional feed protein sources. On the other hand, Bosch et al. (2014) found that in vitro digestibility of insect protein is lower than that of commercially available protein feedstuffs. The quality of lipids depends on 
their fatty acid profiles and therefore the determination of lipids composition in insects is also important. Fatty acid composition of insects was analysed by several authors, e.g., Finke (2002), Barroso et al. (2014) and Oonincx et al. (2015). It is also known, that fatty acid profile could vary significantly, because it reflects the fatty acid composition of animal diet (Sánchez-Muros et al., 2014).

Carbohydrates in insects are present basically in the form of chitin, usually indigestible for monogastric animals, in very low quantities (Finke, 2002). On the other hand, this long chain polymer of $\mathrm{N}$-acetyl glucosamine may exert positive effect on the immune system (van Huis et al., 2013) and its antioxidative, hypocholesterolaemic and prebiotic effects are also known (Halder et al., 2013).

Insects are also a relatively good source of minerals, such as phosphorus, magnesium, sodium or chloride, and trace elements (Finke, 2002). Nevertheless, certain vital element levels are insufficient for the nutritional requirements of vertebrates. One of such elements is calcium (Barker et al., 1998; Finke, 2013).

There are many insects that are suitable for animal feeding. Sánchez-Muros et al. (2014) summarized that there are currently more than $150 \mathrm{com}$ mercially available species, whose nutrient content is species-dependent. Furthermore, not only various species, but also different developmental stages could be used as feed according to individual requirements. Despite the fact that nutritional value of more than 60 insect species is currently known (Sánchez-Muros et al., 2014), the information regarding the differences in insect chemical composition between several stages is only available for a limited number of species. Acheta domestica is one of such species - as an adult it contains more fat and protein but less ash than the nymphs (Barker et al., 1998; Finke, 2002). Regarding Blattodea, Oonincx and Dierenfeld (2012) found in Eublaberus distanti adults higher contents of ash and protein and lower levels of fat than their nymph counterparts, and in adults of Gromphadorhina portentosa approximately the same levels of fat and crude protein as the nymphs.

The investigated cockroaches varied in size, weight, sexual dimorphism and reproduction. In comparison to adults, subadult nymphs are smaller and their wings are not yet fully developed. Adult males of Blatta lateralis are 19-22 $\mathrm{mm}$ long and winged, whereas adult females are $22-25 \mathrm{~mm}$ long, oviparous and brachypterous. Blaptica dubia adults can reach $40 \mathrm{~mm}$ in length. Adult males of this species have long wings that cover the abdo- men entirely, whereas ovoviviparous females have strongly reduced wings. Finally, Blaberus discoidalis are ovoviviparous and their winged adults can reach the length up to $55 \mathrm{~mm}$. They all are considered as suitable feed for animals and are commercially available. Additionally, they are unable to fly or climb on smooth surfaces, which makes them significantly easier to manipulate and prevents from their accidental escape or contamination. Till this time, the information regarding nutritional values of above-mentioned species was either unavailable or concerned only adults, which made the comparison among different developmental stages impossible.

Due to the limited information, this study presents the nutritional value of subadults and adults of three cockroach species (B. dubia, B. lateralis, $B$. discoidalis) and compares the differences between their last two developmental stages from the perspective of nutritional composition. This knowledge will also allow to better understand the dietary habits of insectivorous animals or possibly to meet the requirements of animals, whose nutritional demands have already been standardized.

\section{Material and methods}

\section{Sampling}

All cockroaches were kept in plastic boxes (dimensions: $59 \times 39 \times 28 \mathrm{~cm}=45$ litres for $B$. dubia and $39 \times 28 \times 28 \mathrm{~cm}=22$ litres for $B$. discoidalis and $B$. lateralis) filled with flat egg trays. The boxes were covered by a lid equipped with aluminium insect mesh and no substrate was used. Heating foils were used to maintain a constant temperature of $27{ }^{\circ} \mathrm{C}$, which was thermostatically controlled. All the cockroach colonies were fed dog granules (Brit Care Medium Adult Breed, Vafo, Chrášt'any, Czech Republic) and old bread ad libitum. Slices of fresh vegetables and fruits (i.e. carrot, cucumber, turnip and apple) were provided daily. The vegetable and fruits scraps were constantly removed to prevent the occurrence of mildew. A water source was present in each of the breeding containers. Approximate populations of the colonies were as follows: $B$. discoidalis -700 specimens, B. dubia -1500 specimens and B. lateralis - 1700 specimens (all stages were kept together). Randomly selected subadults and adults (20-40 insects) of all investigated species were individually weighed to determine average weight per insect. Due to the difference in the weight of males and females, these values are reported separately ac- 
cording to sex. Subsequently, samples (about 300 g) were removed from each colony and frozen alive (at $\left.-18{ }^{\circ} \mathrm{C}\right)$. The samples were then lyophilized and homogenized.

\section{Analysis of proximate composition}

All investigated parameters were determined using the methods of European Commission Regulation (EC) No. 152/2009. The dry matter (DM) content was determined after $5 \mathrm{~h}$ of drying at $103{ }^{\circ} \mathrm{C}$. The total amount of nitrogen was evaluated by the Kjeldahl method(ISO 5983-1:2005) using the Kjeltec 2400 analyzer unit (Foss, Hilleroed, Denmark) and crude protein $(\mathrm{CP})$ level was then calculated $(6.25 \times$ total nitrogen). Crude fat (petroleum ether extract; EE) content was determined gravimetrically after extraction with petroleum ether using Soxhlet apparatus SER 146 (Velp, Usmate, Italy). The samples were then mineralized in a muffle furnace at $550{ }^{\circ} \mathrm{C}$ and the total amount of ash was measured. Additionally, chitin content was analysed according to Liu et al. (2012) using hydrolysis with $1 \mathrm{M}$ hydrochloric acid and $1 \mathrm{M}$ sodium hydroxide. Because chitin is a nitrogenous polysaccharide, the nitrogen content was also analysed in these hydrolysed samples to refine total crude protein content. Nitrogen-free extract (NFE) was calculated as:

$$
\mathrm{NFE}=100-(\text { moisture }+\mathrm{CP}+\mathrm{EE}+\text { ash }+ \text { chitin }) .
$$

Finally, the energy content was evaluated using the standard calculation used by other authors such as Finke (2002):

Energy content, $\mathrm{kJ} \cdot \mathrm{kg}^{-1}=$ $=(\mathrm{CP} \times 17)+(\mathrm{EE} \times 37)+(\mathrm{NFE} \times 17)$.

\section{Analysis of amino acid composition}

To describe the protein quality, the amino acid profile was analysed performing acid oxidation in Amino Acid Analyser 400 (INGOS, Prague, Czech Republic). Subsequently, protein quality was evaluated by the essential amino acid index (EAAI), which is based on the content of all essential amino acids except tryptophan in comparison to the reference (eggwhite) protein:

$$
\begin{aligned}
\text { EAAI }= & 10 \sqrt{\frac{\mathrm{mg} \text { of lysine in } 1 \mathrm{~g} \text { of test protein }}{\mathrm{mg} \text { of lysinein } 1 \mathrm{~g} \text { of eggwhite protein }}} \times \\
& \times(\text { etc. for other determined amino acids }) .
\end{aligned}
$$

The determined amino acids were: valine, leucine, isoleucine, tyrosine, phenylalanine, histidine, lysine, arginine, cysteine and methionine.

\section{Analysis of fatty acids}

To determine the lipid quality, the fatty acid profile was analysed by gas chromatography-mass spectrometry technique (GC-MS). Prior to that, the Soxhlet extraction of lipids from samples was performed for $4 \mathrm{~h}$, using petroleum ether. The base esterification method by $0.5 \mathrm{M}$ methanolic $\mathrm{KOH}$ and $\mathrm{BF}_{3}$-methanol was used for fatty acids derivatization (ISO 12966-2:2011). Methyl esters of fatty acids were analysed by GC-MS using Agilent 7890A GC (Agilent, Wilmington, DE, USA) equipped with a Restek Rt-2560 column (length - 100 m; ID $-0.25 \mathrm{~mm}$; film $-0.25 \mu \mathrm{m}$; Restek Corporation, Bellefonte, PA, USA) and coupled to Agilent 5975C single-quadrupole mass detector (Agilent, Wilmington, DE, USA). Hexane was used as a solvent and the sample volume of $1 \mu \mathrm{l}$ was injected in split mode (ratio 50:1) into the injector heated to $225^{\circ} \mathrm{C}$. The initial oven temperature was $70{ }^{\circ} \mathrm{C}$ (hold $2 \mathrm{~min}$ ), ramp1 was up to $225^{\circ} \mathrm{C}$ at $5{ }^{\circ} \mathrm{C} \cdot \min ^{-1}$ (hold $9 \mathrm{~min}$ ) and ramp2 was up to $240{ }^{\circ} \mathrm{C}$ at $5{ }^{\circ} \mathrm{C} \cdot \mathrm{min}^{-1}$ (hold $25 \mathrm{~min}$ ). Helium was used as a carrier gas with the flow rate of $1.2 \mathrm{ml} \cdot \mathrm{min}^{-1}$. The mass spectrometry analysis was carried out in full scan mode, the electron ionization energy was set at $70 \mathrm{eV}$. Methylated fatty acids were identified using a Restek Food Industry FAME mix (cat no. 35077; Bellefonte, PA, USA) and by the comparison of their mass spectra with the National Institute of Standards and Technology Library (NIST, Gaithersburg, MD, USA). The proportions of fatty acids were calculated by area normalization method.

\section{Results}

As expected, the weight of roaches was proved to be species-specific. In all examined species the adult females weighed more than the subadult females, while weights of adult males were always lower than those of the subadults. The DM content amounted $307-422 \mathrm{~g} \cdot \mathrm{kg}^{-1}$ of the specimen fresh weight. In all adults it was found more crude protein but less crude fat and ash than in the subadults of respective species (Table 1). On the other hand, chitin levels showed some species-specific differences: whereas in adult roaches of $B$. discoidalis less chitin content was found than in their subadult counterparts, concentrations were higher in adults of $B$. lateralis. The difference between chitin levels in $B$. dubia adults and their subadult counterparts was less than $1 \mathrm{~g} \cdot \mathrm{kg}^{-1} \mathrm{DM}$. Concentration of calcium and phosphorus (Table 2) was lower than $50 \mathrm{~g} \cdot \mathrm{kg}^{-1} \mathrm{DM}$. In the investigated 
Table 1. Nutrient content of three cockroaches (Blattodea) in adult and subadult stages

\begin{tabular}{|c|c|c|c|c|c|c|c|c|c|c|c|c|c|}
\hline \multirow{3}{*}{ Species } & \multirow{3}{*}{ Stage } & \multicolumn{2}{|c|}{ Average weight } & \multicolumn{9}{|c|}{ Nutrients content } & \multirow{3}{*}{$\begin{array}{l}\text { Energy, } \\
\mathrm{MJ} \cdot \mathrm{kg}^{-1} \mathrm{DM}\end{array}$} \\
\hline & & female & male & moisture & DM & EE & $N \times 6.25$ & $\begin{array}{l}\text { chitin } \\
\text { protein }\end{array}$ & $\mathrm{CP}$ & chitin & ash & NFE & \\
\hline & & \multicolumn{2}{|c|}{ mg per insect } & $\mathrm{g} \cdot \mathrm{kg}^{-1}$ & & \multicolumn{7}{|c|}{$\mathrm{g} \cdot \mathrm{kg}^{-1} \mathrm{DM}$} & \\
\hline Blaptica & subadult & 2034 & 1659 & 578 & 422 & 328 & 547 & 22 & 525 & 65 & 40 & 42 & 22 \\
\hline dubia & adult & 2213 & 1279 & 626 & 374 & 214 & 650 & 20 & 630 & 64 & 49 & 43 & 19 \\
\hline Blaberus & subadult & 3290 & 2612 & 659 & 341 & 236 & 536 & 33 & 503 & 86 & 36 & 139 & 20 \\
\hline discoidalis & adult & 3612 & 2212 & 657 & 343 & 203 & 678 & 26 & 652 & 66 & 42 & 37 & 19 \\
\hline Blatta & subadult & 398 & 290 & 640 & 360 & 363 & 489 & 18 & 470 & 53 & 37 & 77 & 23 \\
\hline lateralis & adult & 552 & 267 & 693 & 307 & 145 & 602 & 18 & 584 & 59 & 51 & 161 & 18 \\
\hline
\end{tabular}

$\mathrm{DM}$ - dry matter; $\mathrm{EE}$ - petroleum ether extract of crude fat; $\mathrm{N} \times 6.25$ - total nitrogen amount; $\mathrm{CP}$ - crude protein; NFE - nitrogen-free extract

Table 2. Calcium and phosphorus content and their ratio of three cockroaches (Blattodea) in adult and subadult stages

\begin{tabular}{lllll}
\hline \multirow{2}{*}{ Species } & Stage & \multicolumn{2}{l}{ Content, $\mathrm{g} \cdot \mathrm{kg}^{-1} \mathrm{DM}$} & Ca:P \\
\cline { 3 - 4 } & & $\mathrm{Ca}$ & $\mathrm{P}$ & ratio \\
\hline Blaptica dubia & subadult & 2 & 43 & $1: 21.5$ \\
& adult & 2 & 47 & $1: 23.5$ \\
Blaberus discoidalis & subadult & 7 & 20 & $1: 2.9$ \\
& adult & 8 & 30 & $1: 3.8$ \\
Blatta lateralis & subadult & 7 & 12 & $1: 1.8$ \\
& adult & 9 & 25 & $1: 1.9$ \\
\hline
\end{tabular}

Table 3. Non-essential amino acid content of three cockroaches (Blattodea) in adult and subadult stages

\begin{tabular}{|c|c|c|c|c|c|c|}
\hline \multirow{3}{*}{ Amino acid } & \multicolumn{6}{|c|}{ Non-essential amino acid content, $\mathrm{g} \cdot \mathrm{kg}^{-1} \mathrm{DM}$} \\
\hline & \multirow{2}{*}{\multicolumn{2}{|c|}{$\begin{array}{l}\text { Blaptica } \\
\text { dubia } \\
\text { subadult adult }\end{array}$}} & \multirow{2}{*}{\multicolumn{2}{|c|}{$\begin{array}{l}\text { Blaberus } \\
\text { discoidalis } \\
\text { subadult adult }\end{array}$}} & \multirow{2}{*}{\multicolumn{2}{|c|}{$\begin{array}{l}\text { Blatta } \\
\text { lateralis } \\
\text { subadult adult }\end{array}$}} \\
\hline & & & & & & \\
\hline Aspartic acid & 26.3 & 28.0 & 33.0 & 25.3 & 22.4 & 39.3 \\
\hline Threonine & 16.5 & 16.5 & 21.4 & 13.9 & 13.6 & 23.8 \\
\hline Serine & 21.2 & 17.7 & 26.1 & 13.9 & 17.0 & 27.9 \\
\hline Glutamic acid & 47.4 & 48.0 & 57.7 & 48.3 & 43.4 & 72.2 \\
\hline Proline & 38.3 & 39.3 & 49.3 & 28.4 & 34.3 & 45.7 \\
\hline Glycine & 98.4 & 166.2 & 116.1 & 69.2 & 66.4 & 128.6 \\
\hline Alanine & 100.0 & 108.9 & 140.1 & 81.5 & 83.8 & 118.4 \\
\hline
\end{tabular}

roaches more phosphorus than calcium was detected and the lowest $\mathrm{Ca}: \mathrm{P}$ ratio was found in B. dubia.

In the examined cockroaches high levels of such non-essential amino acids as glycine and alanine were found (Table 3 ). In comparison to eggwhite, calculated EAAI values ranged from 0.4 to 0.9 , and the highest EAAI was found in adult and subadult $B$. discoidalis roaches (Table 4).
Table 4. Essential amino acid content and essential amino acid index of three cockroaches (Blattodea) in adult and subadult stages

\begin{tabular}{|c|c|c|c|c|c|c|}
\hline \multirow{3}{*}{ Amino acid } & \multicolumn{6}{|c|}{ Essential amino acid content, $\mathrm{g} \cdot \mathrm{kg}^{-1} \mathrm{DM}$} \\
\hline & \multicolumn{2}{|l|}{$\begin{array}{l}\text { Blaptica } \\
\text { dubia }\end{array}$} & \multicolumn{2}{|c|}{$\begin{array}{l}\text { Blaberus } \\
\text { discoidalis }\end{array}$} & \multicolumn{2}{|l|}{$\begin{array}{l}\text { Blatta } \\
\text { lateralis }\end{array}$} \\
\hline & subadult & adult & subadult & adult & subadult & adult \\
\hline Valine & 58.8 & 66.3 & 84.0 & 54.4 & 53.3 & 81.3 \\
\hline Isoleucine & 68.3 & 37.2 & 89.1 & 34.6 & 57.2 & 101.3 \\
\hline Leucine & 36.0 & 64.6 & 26.6 & 61.5 & 18.9 & 9.7 \\
\hline Tyrosine & 58.5 & 46.9 & 62.2 & 42.2 & 47.3 & 59.9 \\
\hline Phenylalanine & 31.2 & 31.9 & 38.9 & 30.6 & 26.6 & 46.7 \\
\hline Histidine & 34.8 & 36.6 & 50.7 & 30.8 & 29.6 & 47.7 \\
\hline Lysine & 57.7 & 62.8 & 73.5 & 60.4 & 48.6 & 94.0 \\
\hline Arginine & 53.8 & 56.1 & 71.3 & 57.2 & 44.9 & 89.8 \\
\hline Cysteine & 2.1 & 1.7 & 1.4 & 2.0 & 0.5 & 0.9 \\
\hline Methionine & 17.2 & 13.6 & 13.4 & 15.5 & 4.0 & 7.8 \\
\hline EAAI & 0.4 & 0.7 & 0.9 & 0.9 & 0.7 & 0.6 \\
\hline
\end{tabular}

EAAI - essential amino acid index

Conversely, contents of methionine and cysteine were the lowest.

In all cockroaches the oleic acid (C18:1cis-9) content was the highest among fatty acids, and ranged from 38.0 to $44.2 \%$ of total fatty acids (Table 5). Only in B. lateralis species more saturated (SFA) than monounsaturated (MUFA) fatty acids were determined. In the remaining two species there were more MUFA. The lowest polyunsaturated fatty acids (PUFA) levels $(9.5 \%$ and $9.6 \%$ for adult and subadult stage, respectively) were found in B. lateralis. On the other hand, the highest PUFA amount (20.9\%) was found in adults of $B$. discoidalis. 
Table 5. Fatty acid profile of three cockroaches (Blattodea) in adult and subadult stages

\begin{tabular}{|c|c|c|c|c|c|c|}
\hline \multirow{3}{*}{ Fatty acid } & \multicolumn{6}{|c|}{ Fatty acid profile, $\%$ of total fatty acids } \\
\hline & \multicolumn{2}{|c|}{$\begin{array}{l}\text { Blaptica } \\
\text { dubia }\end{array}$} & \multicolumn{2}{|c|}{$\begin{array}{l}\text { Blaberus } \\
\text { discoidalis }\end{array}$} & \multicolumn{2}{|l|}{$\begin{array}{l}\text { Blatta } \\
\text { ateralis }\end{array}$} \\
\hline & subadult & adult & subadult & adult & subadult & adult \\
\hline $\mathrm{C} 4: 0$ & ND & ND & ND & ND & ND & ND \\
\hline C6:0 & $<0.1$ & $<0.1$ & $<0.1$ & $<0.1$ & $<0.1$ & $<0.1$ \\
\hline C8:0 & $<0.1$ & $<0.1$ & $<0.1$ & $<0.1$ & $<0.1$ & $<0.1$ \\
\hline $\mathrm{C} 10: 0$ & $<0.1$ & $<0.1$ & $<0.1$ & $<0.1$ & $<0.1$ & $<0.1$ \\
\hline $\mathrm{C} 12: 0$ & 0.3 & 0.3 & 0.1 & 0.1 & 0.2 & 0.1 \\
\hline C14:0 & 2.6 & 2.2 & 1.2 & 1.3 & 1.9 & 1.3 \\
\hline C14:1 cis-9 & 0.1 & 0.1 & $<0.1$ & $<0.1$ & $<0.1$ & $<0.1$ \\
\hline C15:0 & 0.2 & 0.2 & 0.2 & 0.3 & 0.1 & 0.2 \\
\hline C16:0 & 22.8 & 21.6 & 23.4 & 22.9 & 26.8 & 24.7 \\
\hline C16:1 trans- 9 & 0.4 & 0.5 & 0.7 & 0.7 & 0.2 & 0.3 \\
\hline C16:1 cis-9 & 9.8 & 7.7 & 4.4 & 2.6 & 3.3 & 4.5 \\
\hline C17:0 & 0.5 & 0.6 & 0.3 & 0.6 & 0.4 & 0.5 \\
\hline C17:1 cis-10 & 0.3 & 0.5 & 0.2 & 0.3 & 0.1 & 0.2 \\
\hline C18:0 & 7.8 & 8.9 & 6.8 & 8.9 & 18.1 & 17.9 \\
\hline C18:1 trans- 9 & 0.1 & 0.1 & 0.2 & 0.5 & 0.2 & 0.2 \\
\hline C18:1 cis-9 & 40.3 & 42.5 & 44.2 & 40.2 & 38.0 & 39.1 \\
\hline C19:0 & 0.1 & 0.1 & ND & 0.1 & 0.1 & 0.1 \\
\hline C18:2 cis-9,12 & 10.6 & 11.9 & 15.3 & 17.9 & 8.7 & 8.5 \\
\hline $\mathrm{C} 20: 0$ & 0.2 & 0.3 & 0.3 & 0.3 & 0.6 & 0.9 \\
\hline C20:1 cis-11 & 0.3 & 0.3 & 0.3 & 0.3 & 0.2 & 0.3 \\
\hline $\begin{array}{r}\text { C18:3 cis- } \\
9,12,15\end{array}$ & 3.2 & 1.8 & 1.7 & 1.9 & 0.7 & 0.7 \\
\hline C22:0 & 0.1 & 0.1 & ND & ND & $<0.1$ & 0.1 \\
\hline $\begin{array}{l}\text { C20:4 cis- } \\
5,8,11,14\end{array}$ & 0.2 & 0.3 & 0.5 & 1.0 & 0.2 & 0.4 \\
\hline C24:0 & 0.1 & $<0.1$ & $<0.1$ & $<0.1$ & $<0.1$ & $<0.1$ \\
\hline SFA & 34.7 & 34.3 & 32.4 & 34.6 & 48.3 & 45.8 \\
\hline MUFA & 51.3 & 51.6 & 50.1 & 44.6 & 42.2 & 44.7 \\
\hline PUFA & 14.0 & 14.1 & 17.5 & 20.9 & 9.6 & 9.5 \\
\hline
\end{tabular}

ND - not detected; SFA - saturated fatty acids; MUFA - monounsaturated fatty acids; PUFA - polyunsaturated fatty acids

\section{Discussion}

Proximal composition. Information concerning the nutrient content of the investigated species is only available for the adults of $B$. dubia (Yi et al., 2013; Bosch et al., 2014) and young nymphs of B. lateralis (Oonincx and Dierenfeld, 2012). Therefore, the results should be compared mainly with other cockroaches or insect species. In all of the examined cockroaches high concentrations of crude protein (470-652 $\left.\mathrm{g} \cdot \mathrm{kg}^{-1} \mathrm{DM}\right)$ as well as high levels of crude fat $\left(145-363 \mathrm{~g} \cdot \mathrm{kg}^{-1} \mathrm{DM}\right)$ were determined. This means that both subadult and adult cockroaches used in our study are a similar source of protein and lipids like other species of cockroaches (Oonincx and Dierenfeld, 2012; Bosch et al., 2014), house cricket (Acheta domesticus) (Barker et al., 1998; Finke, 2002) and other insects.

The ash content was $36-51 \mathrm{~g} \cdot \mathrm{kg}^{-1} \mathrm{DM}$, which also corresponds with the findings of other authors (Barker et al., 1998; Finke, 2002; Oonincx and Dierenfeld, 2012). Additionally, we found rather low $\mathrm{Ca}: \mathrm{P}$ ratios that are insufficient for the vertebrate diets (NRC, 1995, 2003; Finke, 2002); but these ratios are similar to those reported for most insect species (Barker et al., 1998; Finke, 2002; Oonincx and Dierenfeld, 2012). The above-mentioned results confirm the need for calcium supplements in the insectivore diets. In order to better serve the nutritional requirements of vertebrates, further research should be focused on possibilities of increasing $\mathrm{Ca}$ content in insects (such as gut loading, etc.) to be able to influence the unfavourable $\mathrm{Ca}: \mathrm{P}$ ratio as well as the calcium accumulation in the body of insects.

The chitin content $\left(53-86 \mathrm{~g} \cdot \mathrm{kg}^{-1} \mathrm{DM}\right)$ was similar to that of crickets (Gryllus testaceus) (Wang et al., 2005) and grasshoppers (Acrida cinerea) (Wang et al., 2007). Significantly lower chitinin contents were reported by Finke (2013). However, these differences may result from different methodologies used. Additionally, crude protein content in chitin was $18-33 \mathrm{~g} \cdot \mathrm{kg}^{-1} \mathrm{DM}$, which is clearly more than $4 \mathrm{~g} \cdot \mathrm{kg}^{-1} \mathrm{DM}$ reported by Bernard and Allen (1997).

Amino acid profile. In all tested samples contents of glycine $\left(66.4-166.2 \mathrm{~g} \cdot \mathrm{kg}^{-1} \mathrm{DM}\right)$ and alanine $\left(81.5-118.4 \mathrm{~g} \cdot \mathrm{kg}^{-1} \mathrm{DM}\right)$ were very high. It is more than in other studies focused on the protein quality in cockroaches, e.g., Yi et al. (2013) and Bosch et al. (2014). These differences were probably caused by feed residues in the cockroach digestive tract.

The examined cockroaches, especially $B$. discoidalis, also seem to be a good source of essential amino acids (EAA). The EEAI without tryptophan was $0.4-0.9$, mainly because of high lysine level (48.6-94.0 $\left.\mathrm{g} \cdot \mathrm{kg}^{-1} \mathrm{DM}\right)$. On the other hand, the lowest levels of sulphuric amino acids: cysteine $\left(0.5-2.1 \mathrm{~g} \cdot \mathrm{kg}^{-1} \mathrm{DM}\right)$ and methionine (4-17.2 $\left.\mathrm{g} \cdot \mathrm{kg}^{-1} \mathrm{DM}\right)$ were found. These findings are more or less in line with the results published by other authors. For adult females of the same species, Bosch et al. (2014) reported high contents of valine, leucine, histidine, lysine and arginine, which is consistent with the levels found in B. dubia in this study. Moreover, Józefiak et al. (2016) studied the EAA composition of $B$. lateralis subadult nymphs and found that tyrosine, arginine, valine and lysine were among the first five EAAs, which corresponds to the results obtained in this study. On the other hand, 
the main EAA reported by Józefiak et al. (2016) was leucine, while in this paper the most abundant EAA is isoleucine $\left(101.3 \mathrm{~g} \cdot \mathrm{kg}^{-1} \mathrm{DM}\right.$ for adult stage of B. lateralis).

Fatty acid profile. Finke (2002) and Oonincx et al. (2015) analysed the fatty acid profile of cockroaches and determined the same major fatty acids (mainly the oleic acid) in B. lateralis and B. dubia. Moreover, the presented fatty acids profiles were very similar to those obtained in our study. With a few exceptions, the dominant values of oleic, palmitic and linoleic fatty acids presented in this paper also correspond with the results of other authors (Finke, 2002; Barroso et al., 2014), who investigated fat composition of other terrestrical insect species. In line with these authors, no contents of omega-3 fatty acids such as eicosapentaenoic acid (EPA) and docosahexaenoic acid (DHA) were detected. In this work, some differences in lipids composition were observed between the investigated species, but values within the one species varied only marginally. The results indicate that the fat of tested insects contained high proportion of SFA and MUFA. From this point of view, its nutritional quality is not so high and close to other animal fats. On the other hand, the proportion of PUFA is comparable to commonly used oils such as the olive, sunflower or rapeseed oil (Velíšek, 2014). Moreover, it could even be optimalized or improved during the rearing process by adding suitable supplements to the feeding mixtures for insects.

Comparison of developmental stages. Oonincx and Dierenfeld (2012) comparing two consecutive developmental stages of Turkestan roaches (B. lateralis) found that younger nymphs $\left(2^{\text {nd }}\right.$ instar $)$ contained more crude protein $\left(760.5>628.5 \mathrm{~g} \cdot \mathrm{kg}^{-1} \mathrm{DM}\right)$, more ash $\left(78.8>68.9 \mathrm{~g} \cdot \mathrm{kg}^{-1} \mathrm{DM}\right)$ and less crude fat $\left(144.5<265.0 \mathrm{~g} \cdot \mathrm{kg}^{-1} \mathrm{DM}\right)$ than older nymphs ( $3^{\text {rd }}$ instar). In our study less crude protein $(470<$ $\left.584 \mathrm{~g} \cdot \mathrm{kg}^{-1} \mathrm{DM}\right)$, less ash $\left(37<51 \mathrm{~g} \cdot \mathrm{kg}^{-1} \mathrm{DM}\right)$ and more crude fat $\left(363>145 \mathrm{~g} \cdot \mathrm{kg}^{-1} \mathrm{DM}\right)$ were found in younger subadult nymphs than in adults. However, Oonincx and Dierenfeld (2012) did not determine these concentrations for adult roaches. Therefore, their presumption that earlier developmental stages contain more protein and less fat than older specimens of the same species seems dubious in the light of our findings. Nonetheless, further research is needed. We assume that the nutrient content might be significantly influenced by the various diets of the insects (e.g., total fat concentrations correlate with the energy value of the feed), ecdysis and the timing of the analysis.
In the dry matter of adults $B$. dubia roaches $630 \mathrm{~g}$ of crude protein and $214 \mathrm{~g}$ of crude fat per $\mathrm{kg}$ of DM were found, and these concentrations are similar to those reported by Yi et al. (2013) for this species $(592 \mathrm{~g}$ of crude protein and $214 \mathrm{~g}$ of total fat per $\mathrm{kg}$ of DM) and Tzompa-Sosa et al. (2014) who reported $7.6 \mathrm{~g}$ of total fat from $100 \mathrm{~g}$ of fresh samples. The nutritional composition of roaches at the subadult developmental stage has been unknown until now.

This study was the first to determine the nutrient content of $B$. discoidalis. This content can be compared with that of $E$. distanti, which was selected mainly because it belongs to the same family (Blaberidae) and similar dimorphism (all adults are winged). The chemical composition of this species was reported by Oonincx et Dierenfeld (2012), whose findings partly correspond with our results. E. distanti adults contained more crude protein and ash but less fat than $4-5 \mathrm{~cm}$ long nymphs. However, most of the nutrient concentrations determined in this study (especially crude fat and crude protein) differed from those of $E$. distanti.

\section{Conclusions}

The obtained results showed differences in nutritional value among three studied species (Blaptica dubia, Blaberus discoidalis and Blatta lateralis). However, they were not as clear as the differences between adult and subadult cockroaches of the same respective species. All adults were better source of crude protein, ash and calcium, but contained less fat, than the subadults. On the other hand, it was determined that the quality (unlike the quantity) of lipids and proteins remained essentially the same.

\section{Acknowledgements}

This work was supported by the Internal Grant Agency of the Czech University of Life Sciences Prague (CIGA), project No. 20152004. We are very grateful to Brian Kavalir for his proofreading services. We would also like to thank Matyáš Orsák for analysis of calcium and phosphorus.

\section{References}

Barker D., Fitzpatrick M.P., Dierenfeld E.S., 1998. Nutrient composition of selected whole invertebrates. Zoo Biol. 17, 123-134, https://doi.org/10.1002/(SICI)1098-2361(1998)17:2<123:: AID-ZOO7>3.0.CO;2-B 
Barroso F.G., de Haro C., Sánchez-Muros M.-J., Venegas E., MartínezSánchez A., Pérez-Bañónc C., 2014. The potential of various insect species for use as food for fish. Aquaculture 422-423, 193-201, https://doi.org/10.1016/j.aquaculture.2013.12.024

Bernard J.B., Allen M.E., 1997. Feeding captive insectivorous animals: Nutritional aspects of insects as food. Nutrition Advisory Group Handbook, Fact Sheet 3, 1-7

Bosch G., Zhang S., Oonincx D.G.A.B., Hendriks W.H., 2014. Protein quality of insects as potential ingredients for dog and cat foods. J. Nutr. Sci. 3, e29, https://doi.org/10.1017/jns.2014.23

European Commission Regulation (EC), 2009, No. 152/2009. Official Journal of the European Union. Available from: http:// eur-lex.europa.eu/legal-content/EN/ALL/?uri=CELEX\% 3A32009R0152

Finke M.D., 2002. Complete nutrient composition of commercially raised invertebrates used as food for insectivores. Zoo Biol. 21, 269-285, https://doi.org/10.1002/zoo.10031

Finke M.D., 2013. Complete nutrient content of four species of feeder insects. Zoo Biol. 32, 27-36, https://doi.org/10.1002/ zoo. 21012

Halder S.K., Adak A., Maity C., Jana A., Das A., Paul T., Ghosh K., Das Mohapatra P.K., Pati B.R., Mondal K.C., 2013. Exploitation of fermented shrimp-shells hydrolysate as functional food: Assessment of antioxidant, hypocholesterolemic and prebiotic activities. Indian J. Exp. Biol. 51, 924-934

ISO 5983-1:2005, 2005. Animal feeding stuffs - Determination of nitrogen content and calculation of crude protein content - Part 1: Kjeldahl method. International Organization for Standardization. Geneva (Switzerland)

ISO 12966-2:2011, 2011. Animal and vegetable fats and oils - Gas chromatography of fatty acid methyl esters - Part 2: Preparation of methyl esters of fatty acids. International Organization for Standardization. Geneva (Switzerland)

Józefiak D., Józefiak A., Kierończyk B., Rawski M., Światkiewicz S., Długosz J., Engberg R.M., 2016. Insects - a natural nutrient source for poultry - a review. Ann. Anim. Sci. 16, 297-313, https://doi.org/10.1515/aoas-2016-0010

Liu S., Sun J., Yu L., Zhang C., Bi J., Zhu F., Qu M., Jiang C., Yang Q., 2012. Extraction and characterization of chitin from the beetle Holotrichia parallela Motschulsky. Molecules 17, 4604-4611, https://doi.org/10.3390/molecules17044604
NRC, 1995. Nutrient Requirements of Laboratory Animals. $4^{\text {th }}$ Edition. National Academy Press. Washington, DC (USA)

NRC, 2003. Nutrient Requirements for Nonhuman Primates. $2^{\text {nd }}$ Edition. National Academic Press. Washington, DC (USA)

Oonincx D.G.A.B., Dierenfeld E.S., 2012. An investigation into the chemical composition of alternative invertebrate prey. Zoo Biol. 31, 40-54, https://doi.org/10.1002/zoo.20382

Oonincx D.G.A.B., van Broekhoven S., van Huis A., van Loon J.J.A., 2015. Feed conversion, survival and development, and composition of four insect species on diets composed of food byproducts. PLoS ONE 10, e0144601, https://doi.org/10.1371/ journal.pone.0144601

Sánchez-Muros M.-J., Barroso F.G., Manzano-Agugliaro F., 2014. Insect meal as renewable source of food for animal feeding: a review. J. Clean. Prod. 65, 16-27, https://doi.org/10.1016/j. jclepro.2013.11.068

Tzompa-Sosa D.A., Yi L., van Valenberg H.J.F., van Boekel M.A.J.S., Lakemond C.M.M., 2014. Insect lipid profile: aqueous versus organic solvent-based extraction methods. Food Res. Int. 62, 1087-1094, http://dx.doi.org/10.1016/j.foodres.2014.05.052

van Huis A., Van Itterbeeck J., Klunder H., Mertens E., Halloran A., Muir G., Vantomme P., 2013. Edible insects: Future prospect for food and feed security. FAO Forestry Paper 171, pp. 201

Velišek J., 2014. The Chemistry of Food. Wiley-Blackwell. Chichester (UK)

Wang D., Zhai S.W., Zhang C.X., Bai Y.Y., An S.H., Xu Y.N., 2005. Evaluation on nutritional value of field crickets as a poultry feedstuff. Asian-Austalas. J. Anim. Sci. 18, 667-670, https:// doi.org/10.5713/ajas.2005.667

Wang D., Zhai S.-W., Zhang C.-X., Zhang Q., Chen H., 2007. Nutrition value of the Chinese grasshopper Acrida cinerea (Thunberg) for broilers. Anim. Feed Sci. Technol. 135, 66-74, https:// doi. org/10.1016/j.anifeedsci.2006.05.013

Yi L., Lakemond C.M.M., Sagis L.M.C., Eisner-Schadler V., van Huis A., van Boekel M.A.J.S., 2013. Extraction and characterisation of protein fractions from five insect species. Food Chem. 141, 3341-3348, https://doi.org/10.1016/j.foodchem.2013.05.115 